\title{
FORMATION OF PARTICULATE MATTER DEPENDING ON THE AMOUNT OF COMBUSTION AIR
}

\author{
Jozef JANDAČKA, Štefan PAPUČíK, Radovan NOSEK, Jana JURKECHOVÁ• \\ Abstract:The paper deals about the impact of the amount of combustion air and its \\ allocation between primary, secondary and tertiary entrance to the combustion \\ process. Concentration of emission and heat power of source can be affected by \\ several factors. One of the important factors is the amount of combustion air and \\ its allocation to primary and secondary combustion air. The paper includes a \\ proposal of experimental equipment, where the effect of the amount of combustion \\ air to formation emission was examined. The measurement methodology, \\ measured results and analysis of the achievements are also described.
}

\section{INTRODUCTION}

Nowadays, much attention is paid to environmental protection. Manufacturers of fireplaces improve their products, which give the user comfort. The economic reasons lead people to use in addition to central heating and heating stoves, fireplaces, fireplace stoves. Stoves and fireplaces are a modern heating source with a much smaller release of fumes than traditional stoves, and also makes better use of wood energy and thus saving fuel. Modern modifications allow an increase of heating efficiency and limit the formation of flue gas. In particular, the way of fuel combustion is reflected in fuel consumption and emission parameters. Based on this knowledge were carried out measurements and the results deals with the impacts of the amount of combustion air to the formation of particulate matter.

\section{EXPERIMENTAL DEVICE}

As the heat source was used fireplace rated at $6 \mathrm{~kW}$ (Fig. 1.). As fuel was used wood with a moisture content $11.15 \%$ and calorific value of $16420 \mathrm{~kJ}^{\mathrm{kg}} \mathrm{kg}^{-1}$.

The three air inlets were applied in the experimental measurements (see Fig. 2.)

- $\quad$ primary (frontal) - airflow through the grate and ashtray towards fuel. Primary air is needed in the combustion process, so an ashtray must be emptied so often in order to

\footnotetext{
-Prof.JozefJandacka, PhD. - University of Zilina, Univerzitna 1, 01026 Zilina, Slovakia, e-mail: jozef.jandacka@fstroj.uniza.sk, Ing.ŠtefanPapučík, PhD. - University of Zilina, Univerzitna 1, 01026 Zilina, Slovakia, e-mail: stefan.papucik@fstroj.uniza.sk

Ing. Radovan Nosek, PhD. - University of Zilina, Univerzitna 1, 01026 Zilina, Slovakia, e-mail: radovan.nosek@fstroj.uniza.sk,

Ing. Jana Jurkechová - University of Zilina, Univerzitna 1, 01026 Zilina, Slovakia, e-mail: jana.jurkechova@fstroj.uniza.sk
}

This is an Open Access article distributed under the terms of the Creative Commons Attribution License 2.0, which permits unrestricted use, distribution, and reproduction in any medium, provided the original work is properly cited. 
ensure a supply of primary air. Ensures the evaporation of water from the fuel and the flammable gases are released;

- $\quad$ secondary (back) - process using residual combustible gases that would normally escape through the chimney. There is an increase in efficiency and thus lower fuel consumption;

- $\quad$ tertiary (top) - used for blowing off the windshield and prevents clogging, also contributes to improvement of combustion process and reducing emissions. Fireplace is designed for burning of piece wood.

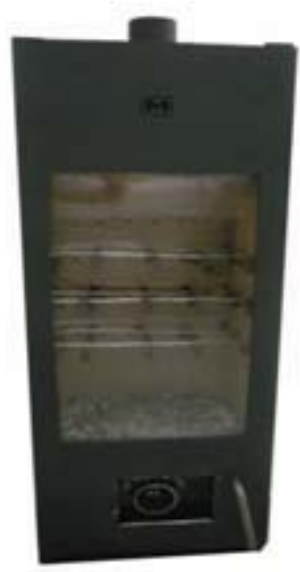

Figure 1: Experimental device -Fireplace
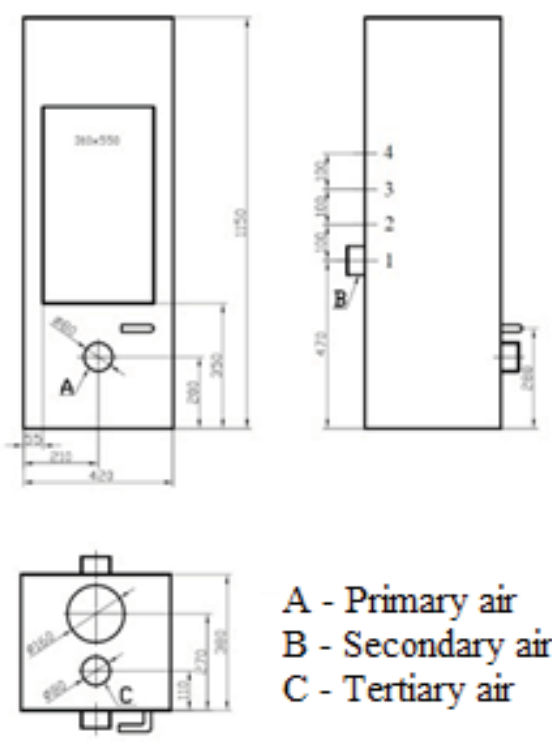
A - Primary air
B - Secondary air
C - Tertiary air

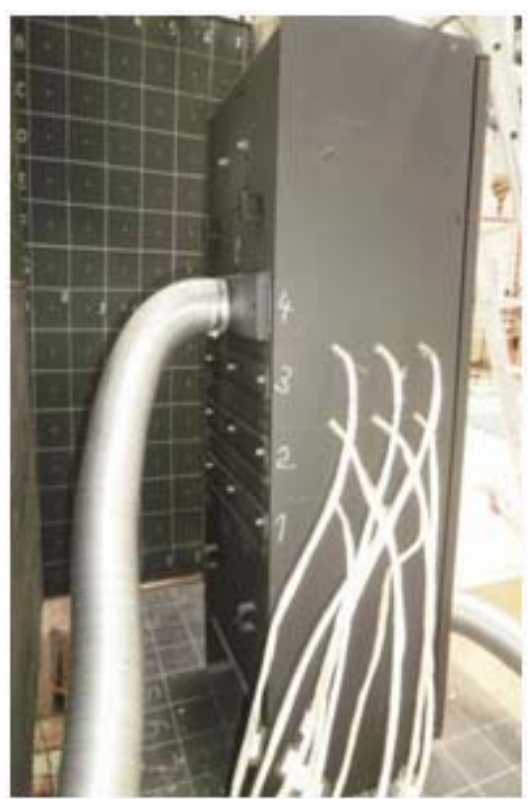

Figure 2: Location of combustion air inlets

Combustion air inlets were locked onto the heat source. The amount of supply air to the combustion process was measured by an anemometer. Combustion process was controlled by the supply of primary, secondary and tertiary air. Each air inlet has a damper. The damper has eight positions of adjustment from 0 to 7 , which can regulate the amount of combustion air. In order to evaluate the quality of combustion process, the gas composition was measured by gas analyser. Test equipment is shown in Figure 3. 


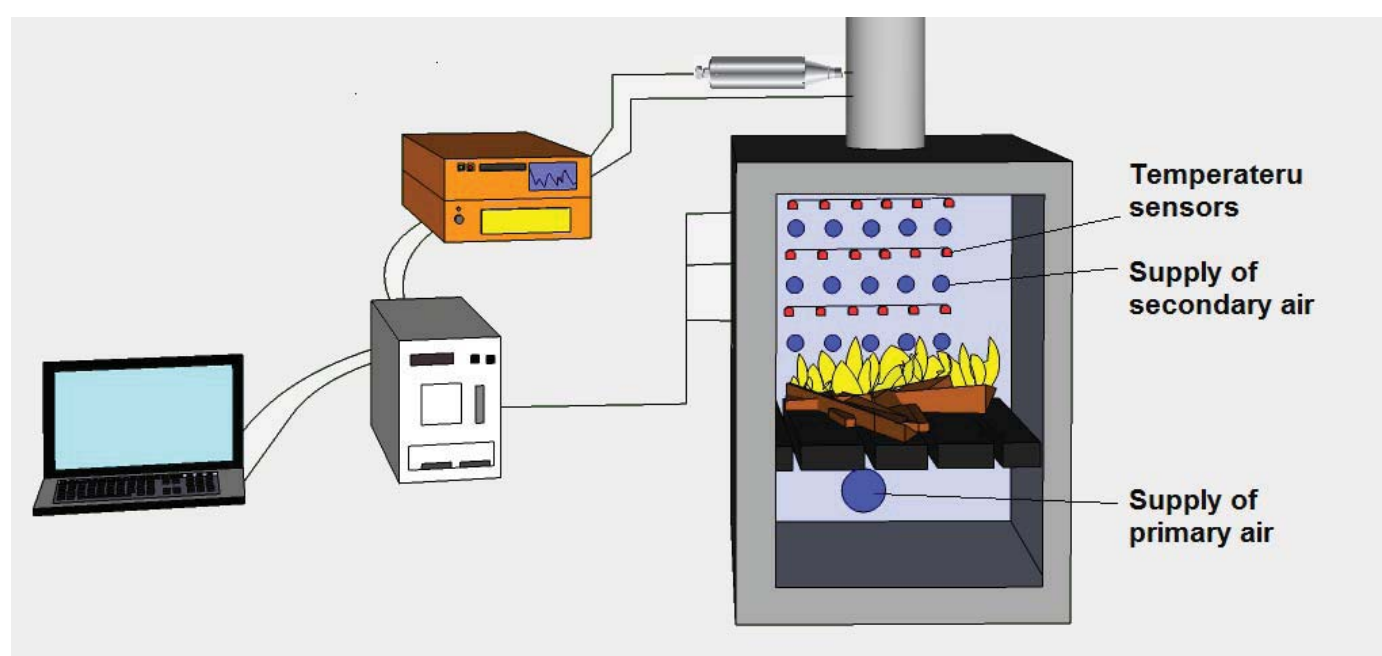

Figure 3: Scheme of experimental device

\section{ANALYSIS OF MEASURED RESULTS}

During the measurements were recorded concentrations of following emissions: $\mathrm{CO}, \mathrm{CO}_{2}$, $\mathrm{SO}_{2}, \mathrm{NO}, \mathrm{O}_{2}, \mathrm{TOC}$ in the flue gas. The amount of combustion air was varied by changing the position of damper or changing the position of air inlet on the back of fireplace. Amount of primary combustion air affected the concentrations of emission and performance parameters of the heat source. Damper is closed gradually from position 0 to position 7, which adjusted the amount of combustion air. Secondary and tertiary air supply was fully open during the experiments. Each position of the damper was measured but significant changes were seen at positions $0,2,5,7$. Concentration of NO emissions achieved during the whole measurement were in an average value of about 40 ppm. Measured carbon dioxide concentrations were very low around 3.3\%. Were also measured low concentrations of sulfur dioxide $(9 \pm 3 \mathrm{ppm})$, which is typical for biomass containing low amount of sulfur in its composition.

Measurement of secondary air takes place gradually in four rows in experimental fireplace. In each row were performed measurements for different position of damper: 0 , 2, 5, 7. Primary and tertiary air intake was fully open during the measurements for different position of damper. Amount of secondary air has a negligible effect on the concentration of $\mathrm{CO}_{2}, \mathrm{NO}$ and $\mathrm{SO}_{2}$. Change in the amount of secondary air have the greatest impact on the $\mathrm{CO}$ concentration. Maximum $\mathrm{CO}$ concentrations were measured when the secondary air supply was connected in the second row. By reducing the amount of tertiary combustion air slightly increased $\mathrm{NO}_{\mathrm{x}}$ emissions, $\mathrm{CO}_{2}$, while there was a significant reduction in $\mathrm{CO}$. 


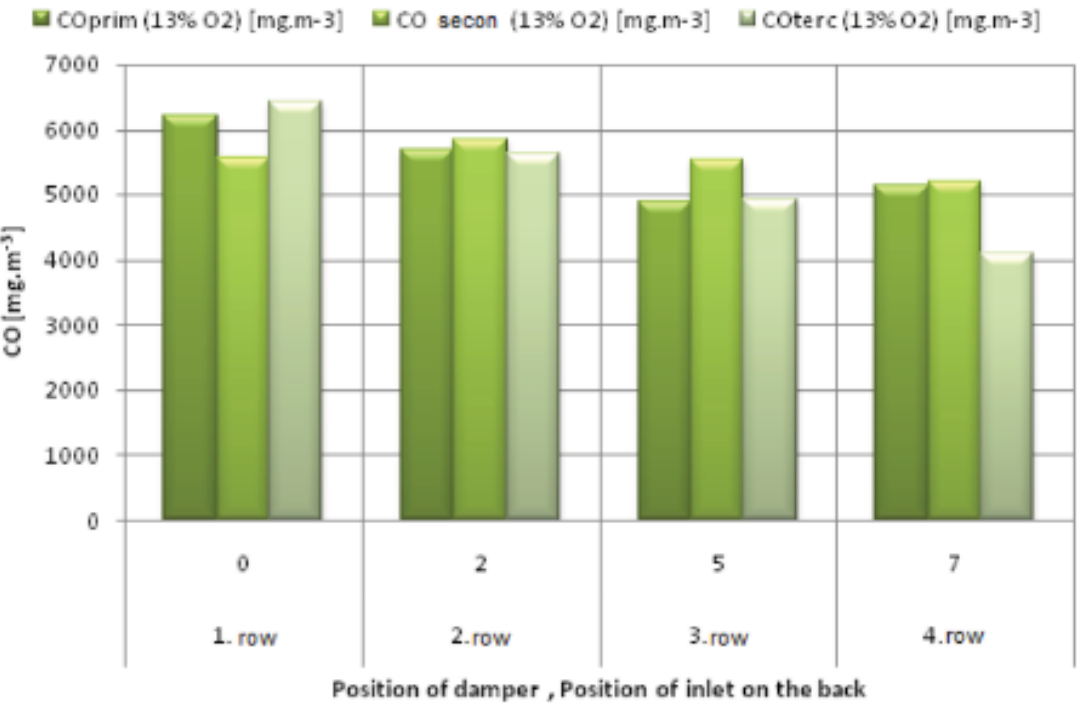

Figure 4: Dependence of CO on air inlet

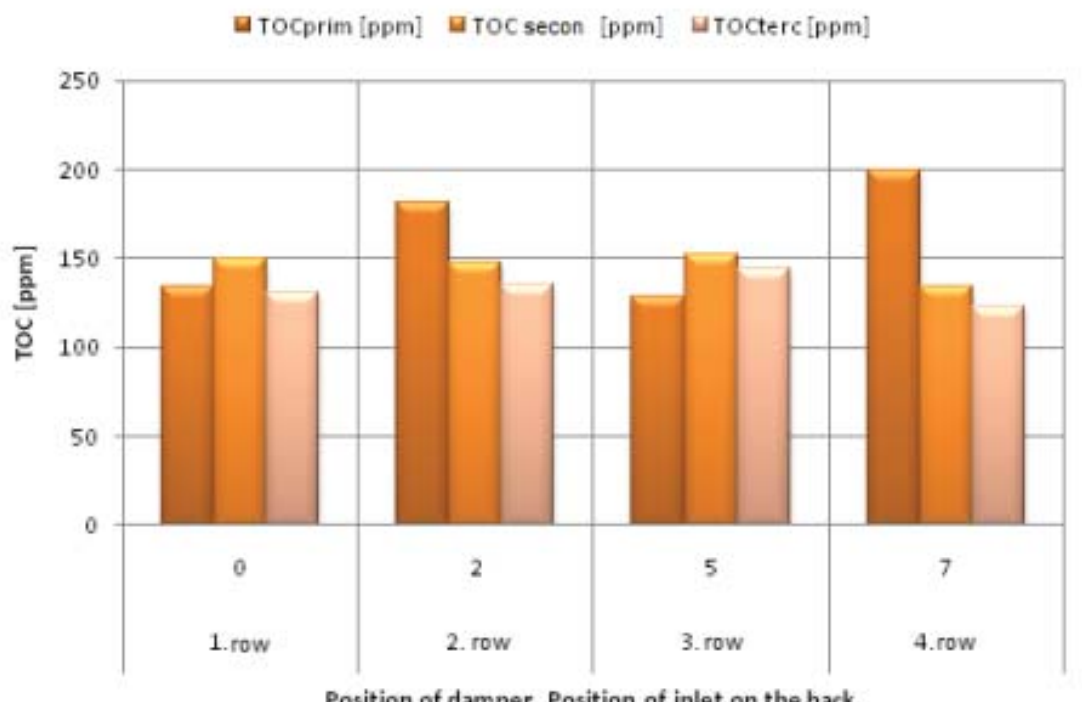

Figure 5: Dependence of TOC on air inlet 


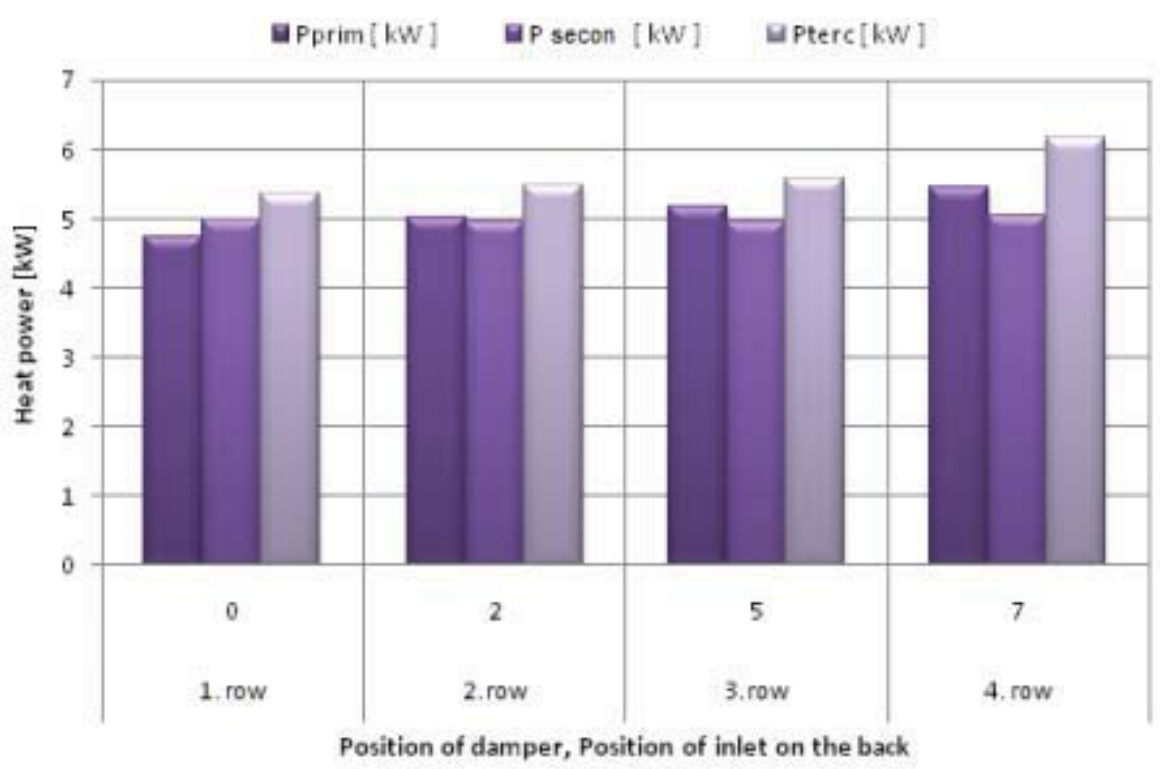

Figure 6:Dependence of heat power on air inlet

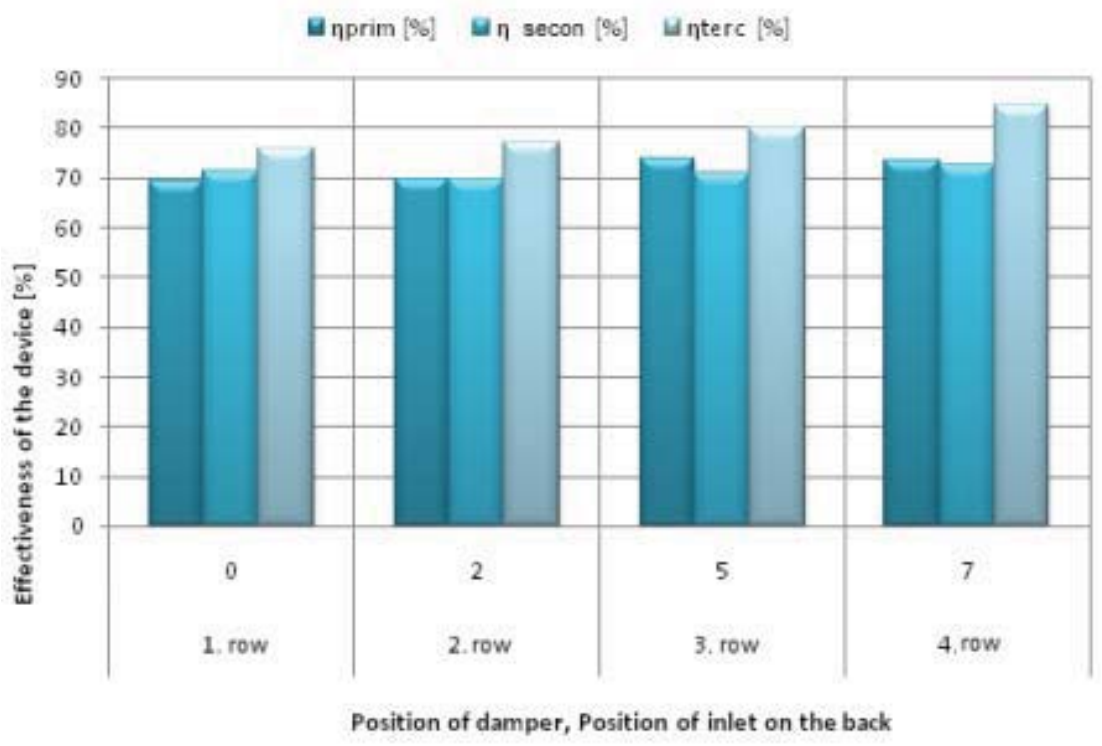

Figure 7:Dependence of device effectiveness on air inlet

Increased performance and efficiency of the experimental test device showed meaningful changes in the tertiary air inlet. The smaller was the amount of tertiary air, the higher output and efficiency of the device was registered.

The following graphs (see Fig. 5 to 7) show carbon monoxide CO, tough organic carbon TOC, performance and effectiveness, depending on the flow of air (primary, secondary and tertiary) and position of damper in the secondary inlet. The highest concentrations of carbon monoxide were measured in combustion with high amount of combustion air. The minimum concentrations of carbon dioxide was emitted, when the top inlet and rear inlet were closed.

On the figure 8 are shown the minimal and maximal values of measured particulate matter concentrations (PM). Measurement of PM for all fully open combustion air reached 
concentration $21 \mathrm{mg} \cdot \mathrm{m}^{-3}$. Minimum concentration of $\mathrm{PM}$ was registered with the involvement of secondary supply in the second row, where only $13,09 \mathrm{mg} \cdot \mathrm{m}^{-3}$ was measured.

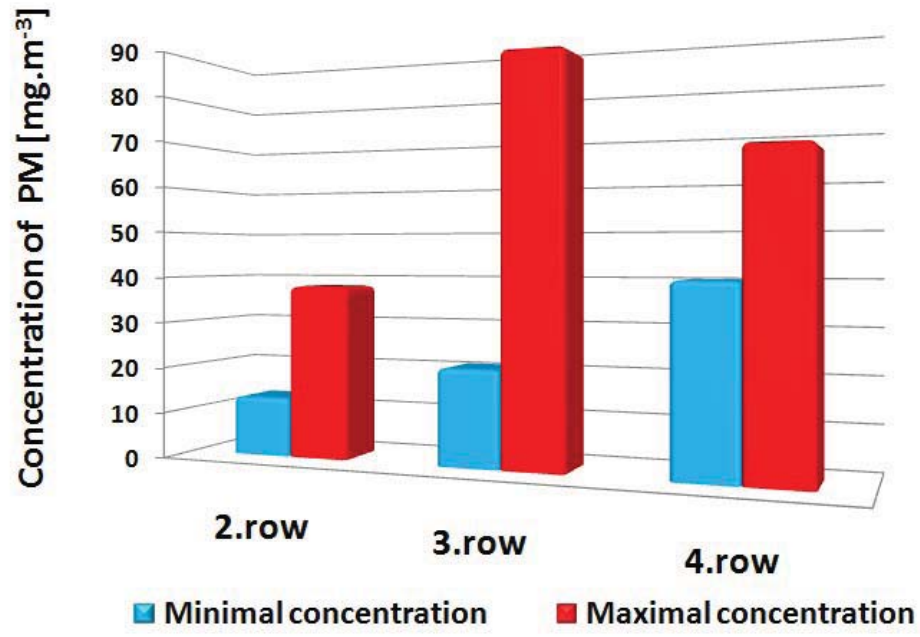

Figure 8:Dependence of PM on air inlet

\section{Conclusions}

Amount of combustion air and proper distribution between primary, secondary and tertiary inlet has a significant impact on emissions, power and efficiency of heat sources. The PM emission arising from the combustion in the fireplace shows that the maximum concentrations were measured when lower volume of the air was supplied into the combustion process. Can be concluded that in terms of PM is advantageous to supply higher amount of combustion air.

Experimental measurements show that manufacturers of heat sources must pay attention to this problem in order to achieve the best operating parameters.

\section{ACKNOWLEDGMENT}

Authors are grateful for the support of experimental works by project KEGA No. 3/7371/09.

\section{REFERENCES}

[1] Dzurenda, L.:Spal'ovaniedreva a kôry, Vydavatelstvo TU voZvolene. 2005.

[2] Huzvar J., Kapjor, A.: Micro-cogeneration including the conversion of chemical energy of biomass to electric energy and the low potential heat, Published Global journal of technology and optimization, 2011

[3] Chabinski, M., Kubica, K., Szlęk, A.: Influence of control algorithm on efficiency and pollutant emission in small capacity stoker boiler, The 1st International Congress on Thermodynamics, 4-7 September 2011 Poznań.

[4] Chabiński, M. ,Szlęk, A.: Propozycjawyznaczaniasprawnościkotłówmałejmocy, ArchiwumSpalania Vol.11 (2011) Nr1-2. 
[5] Labaj, J., Kapjor, A., Papucik, S.: Alternatívnepalivá pre energetiku a dopravu, Published - JurajŠtefuň - GEORG, 2011

[6] Kizek, J.;Zsigraiova,

Z.: Experimentalnestanoveniespalovacichrychlostiplynnychpaliv zvyšenymobsahominternychzloziek, In: ActaMetallurgicaSlovaca. 2001, 7(3), 281-288.

[7] Kostial, I.; Spisak, J.; Mikula, J.; Glocek J.:Metodyenergetickeho zhodnocovania biomasy a odpadov, zbornik z konferencie Moderne procesy spracovania odpadov, vydala Technicka univerzita v Kosiciach, 2007.

[8] Lenhard, R., Gavlas, S.: CFD simulation of passive the chilled beam in a room. Erin 2011, 5th Annual International Travelling Conference for Young Researchers and PhD students. ISBN 978-80-89347-04-9, 2011, roč. 5.

[9] Mihalov, P.; Carnogurska, M.:Navrhregulaciekotla PK4. ACTA MECHANICA SLOVACA, 1999, (3) 153 - 158.

[10] Nosek, R.; Jurkechova, J.; Papucik, S.;Jandacka, J.: Influence of fuel supply to in small capacity boiler on efficiency and pollutant emissions, Experimental Fluid Mechanics. 2010.

[11] Vitazek, I., Tirol, J., Havelka, J.:Analýzaspalínprispalovaníbiomasy, Published Strojárstvo, 2009

[12] Vaszi, Zs.,Varga, A.: Design and verification of the mathematical model for detecting the throughput of the compressor stations, 2009.In: ActaMetallurgicaSlovaca. Roč. 15, č. 2 (2009), s. 117-125. 